Preparing Students for Workplace Challenges: Introducing a Module on the ADA

Michael J. Fitzgerald and Judi Brownell

Cornell University 


\section{Preparing Students for Workplace Challenges: Introducing a Module on the ADA}

On July 26, 1990, President George Bush signed into law the Americans with Disabilities Act (ADA). This historic legislation gives civil rights Protection to individuals with disabilities, similar to that provided to individuals on the basis of race, sex, national origin, and religion. The ADA guarantees equal opportunity for individuals with disabilities in the areas of employment, state and local government services, Public transportation, privately operated transportation available to the public, places of public accommodation, and telecommunications (U.S. Equal Employment Opportunity Commission [EEOC], 1991b).

The legislation, which addresses a variety of needs affecting a minimum of 43 million Americans with physical or mental disabilities, may be the most sweeping piece of civil rights legislation since the Civil Rights Act of 1964. The scope of its ramifications ranges from the removal of physical barriers and the effects on new construction to its impact on schools, transportation systems, parks, hospitals, and virtually every common public area in the United States (Smith, 1992). There is no question that the ADA is now and will continue to significantly affect private businesses, state and federal government, and, in particular, the hospitality industry.

This article has three specific purposes: first, to show the importance of the ADA to hospitality practitioners; second, to illustrate the need for hospitality educators to take a leading role in addressing issues regarding the employment of disabled people; and finally, to illustrate how hospitality educators can use this case method to not just discuss the substance of the law itself, but to actually involve students in issues surrounding this legislation. Only in this way will students begin to develop the strategies necessary to deal with the interpersonal implications and 
complexities of managing in the ADA era. This article describes the major provisions of the legislation. Then it presents a classroom module, and follows with a case that can be used to stimulate discussion in almost any management class.

\section{Major Provisions of the ADA}

Two parts of the ADA are particularly relevant to hospitality management studentsTitle I and Title III. They deal specifically with the private sector employment issues typical in hospitality operations. As of July 26,1992, Title I of the ADA prohibits any employer from discriminating against a "qualified individual with a disability" in all employment practices, including job application procedures, hiring, firing, discharge, advancement, compensation, training, recruitment, tenure, advertising, layoff, leave, fringe benefits, and all other terms, conditions, and privileges of employment (EEOC, 1991a).

Despite almost 20 years of coordinated efforts by private and publicly funded institutions to improve the situation of those with disabilities, employment opportunities have remained the major obstacle to their advancement. A poll of people with disabilities, conducted by the Louis Harris Company (International Center for the Disabled, 1985), established that two thirds (67\%) of all Americans with disabilities between the ages of 16 and 64 are unemployed. Moreover, only one in four (25\%) is employed full time.

Title III of the ADA prohibits any private entity that owns, leases, or operates a place of public accommodation from discriminating against an individual on the basis of disability (U.S. Department of Justice [DOJ], 1991 b]). Broader than Title I, the protections within this title extend to guests and patrons as well as employees. Places of public accommodation include over 
live million private establishments, such as restaurants, hotels, theaters, convention centers, stores, hospitals, museums, and even bowling alleys.

As is readily apparent, the ADA has a variety of implications for the hospitality industry. First, as a major and growing employer, the hospitality industry is subject to all the provisions and guidelines set out in Title I. Second, Title III specifically addresses places of public accommodation, a category into which almost all hospitality organizations fall. Because the practices of hospitality managers are affected by both Title I and Title III legislation, the ADA becomes a particularly influential force in shaping our industry’s employment and human resources practices and policies. Hospitality management students must become familiar with this legislation and must be prepared to provide thoughtful and appropriate responses to the wide range of potential challenges the ADA creates.

\section{Bringing the ADA into the Classroom}

Hospitality educators who are convinced of the importance of the ADA to future managers have a variety of options in approaching this topic within classroom settings. Clearly, an entire course could be devoted to the specific management responsibilities and obligations that accompany this legislation. In the majority of circumstances, however, ttie most feasible way to introduce students to the ADA and its implications is through modules within the context

of more traditional hospitality management courses, such as an Introductory Human Resources Management course or a Principles of Management course.

Exposing students to the ADA and its implications early in their coursework will enable them to consider related issues throughout their upper-level courses. Offerings such as Hospitality Law, Organizational Behavior, Organizational Change, Risk Management, Properties 
and Facilities Management, and Management Policy and Strategy are among the wide range ol courses in which ADA-related issues might be discussed.

Although there are a variety of ways to address the ADA, this paper presents a teaching module that can most easily be introduced into lower-level human resources management or principles of management offerings. Since hotel students tend to be very pragmatic, they seek applications for the theory presented. This orientation is consistent with the topic of the ADA, because this legislation directly affects the operations, construction, and development of all hotels and restaurants.

The module described is best presented after the class has had some exposure to introductory legal compliance and basic employee relations issues. It is essential that students have an understanding of employee and employer rights and responsibilities, as well as the relationships between government regulation and private enterprise. Once this groundwork has been established, introduction of the ADA is a logical next step.

\section{The ADA Module}

The framework presented here can readily be adapted to specific program and course requirements. To present the information in as useful a format as possible, the module is designed as a 3-day instructional plan.

\section{Day One}

Before the first class period, students should study the major sections and implications of the ADA. Required and recommended readings might include: 
- Accommodating all guests: The Americans with Disabilities Act and the lodging industry. (1992). Washington, D.C.: American Hotel \& Motel Assoc.

- Brown, F. J, \& Bass, A. S. (1990). The Americans with Disabilities Act of 1990: A guide to compliance. Wash., D.C.: Arent, Fox, Kinlner, Plotkin, \& Kahn.

- U.S. Equal Employment Opportunity Commission. (1991). The Americans with Disabilities Act: Your employment rights as an individual with a disability. Washington, D.C.: U.S. Government Printing Office.

- U.S. Equal Employment Opportunity Commission (1991). The Americans with Disabilities Act, your responsibilities as an employer. Washington, D.C.: U.S. Government Printing Office.

These selected publications are written as guides for employers and, consequently, are much easier for students to understand. An appropriate means of introducing the three titles within the act, for instance, would be to divide the class into three small groups and assign each group one title to analyze.

\section{Assignment}

At the end of the first class, students would be assigned a hotel or restaurant company to contact to determine what policies, changes, and general implications the ADA has had for that particular organization. Sample questions might include:

- Is there a specific ADA function or department? Is it handled through the human resources department, operations, or legal office? 
- Is the ADA handled at the corporate office, regionally, or at the individual property level?

- What are some examples of ADA-related issues that have arisen?

- What, generally, is the corporate attitude toward this legislation? How has it influenced other organizational policies and procedures?

- What implications does the legislation have for new construction? Transportation? Hiring?

- What individual programs exist at the corporate level? At the unit level?

- How many persons with disabilities are employed by the company? Is the company actively recruiting or promoting persons with disabilities? What are some examples?

\section{Day Two}

A class tally of how individual companies have handled their ADA efforts would then be in order. Appropriate categories might include:

- How many companies have corporate ADA offices?

- How many are administered by the legal department? By human resources?

Students can discuss the advantages and disadvantages of various corporate strategies and offer their own thoughts and recommendations regarding how they might interpret and handle the legislation differently.

A closing discussion might focus on the challenges of the ADA to a single unit operation. The instructor could discuss realistic implications of reasonable accommodation and what it means to the hotel and restaurant manager, focusing on specific examples whenever possible. 


\section{Assignment}

Divide the class into groups of three or four and give each group a copy of a disabilities case, "The Tale of Tyrone" (featured later in the article) to read and prepare for the next class meeting. Although the case addresses important ADA issues, additional scenarios might be created that would encourage students to make management decisions regarding more specific ADA topics. Examples might be a hiring situation of a physically disabled person that involves considerable accommodation. Another might be the promotion of a mentally disabled person to shift supervisor over nondisabled persons, and, in the hospitality industry, it might be particularly useful to include an AIDS-related incident. One of the most controversial aspects of ADA legislation is the protection of the AIDS sufferer.

\section{Day Three}

Groups meet and discuss reactions to the case during the first part of the class session. After a designated period, each team presents its decisions to the class. In light of their past work, students should now be able to explore the ADA implications within a realistic framework.

The case approach stimulates active participation and discussion; it helps nondisabled persons understand the types of challenges the disabled person faces and how, as hospitality managers, they will have a key role in interpreting and implementing ADA legislation. Three days may not be enough time to spend on the ADA, but the assignments suggested here are meant to begin sensitizing students and increasing their awareness of one aspect of the new labor force 


\section{Conclusion}

During the past two decades, educational and vocational training opportunities for individuals with disabilities have greatly improved, while corresponding employment opportunities in the private sector and access to places of public accommodation have not (Brown \& Bass, 1990). The ADA is designed to address these employment obstacles. This article has shown the importance of increased familiarity with this legislation. Such familiarity is vital for both operational effectiveness and in addressing larger societal concerns. Enforcement of the ADA in the years ahead will enable individuals with disabilities to realize the previously elusive goal of full participation in American society. This participation can be facilitated by sensitive, informed, and socially conscious hospitality managers. 


\section{References}

Brown, S. J, \& Bass, A. S. (1990). The Americans with Disabilities Act of 1990: A guide to compliance. Washington, D.C.: Arent, Fox, Kintner, Plotkin \& Kahn.

Smith, J. H,, Jr. (1992). A study of handicapped employment in the hospitality industry. Hospitality \& Tourism Educator, 4(3), 16-25.

International Center for the Disabled (ICD). (1985). ICD Survey II: Employing disabled Americans. Louis Harris Associates, Inc.

U. S. Department of Justice, Civil Rights Division,

Office on the Americans with Disabilities Act. (1991a). Title I highlights. Washington, D.C.: U.S. Government Printing Office.

U. S. Department of Justice, Civil Rights Division,

Office on the Americans with Disabilities Act. (1991b). Title III highlights. Washington, D.C.: U.S. Government Printing Office.

U. S. Equal Employment Opportunity Commission.

(1991a). The Americans with Disabilities Act: Your employment rights as an individual with a disability. Washington, D.C.: U.S. Government Printing Office.

U. S. Equal Employment Opportunity Commission (1991 b). The Americans with Disabilities Act: Your responsibilities as an employer. Washington, D. C.: U.S. Government Printing Office.

U. S. Equal Employment Opportunity Commissions. (1991 c). The Americans with Disabilities Act: Questions and answers. Washington, D.C.: U. S. 


\section{Exhibit 1. The Tale of Tyrone}

\section{The Tale of Tyrone}

In seven years as director of human resources at the Hightower Hotel, there had been a number of predicaments like the one Leslie now faced. Repetition, however, never seemed to ease the anxiety surrounding a termination action. This particular situation was complicated further by the special circumstances surrounding Tyrone Travis, the employee she was considering terminating.

As was her custom when faced with a difficult situation, Leslie went for a long walk to consider all the facts and circumstances of the last several days. She found that the combination of fresh air and isolation helped her mind. Leslie strongly believed that important personnel decisions required an objective assessment, which was not always easy when surrounded by the management team trappings of the workplace.

\section{Tyrone's Story}

Tyrone's story was a long and complicated one. He had come to the hotel five years ago in a supported employment project with the city social services department. Tyrone suffered from Downs Syndrome and had an IQ of between 70 and 75. Coming from a low income, rural family, Tyrone never received any specialized training and never attended any formal school. His widower father and older sister had done the best they could to teach Tyrone some basic living skills, but he never developed the ability to read, write, or even sign his own name.

At 16, Tyrone was enrolled in a community sheltered workshop program where he was employed five days a week stuffing envelopes and sorting mail. After three years in the sheltered 
workshop environment, the workshop directors felt Tyrone was ready for mainstream employment.

Leslie had long been interested in pursuing some kind of joint employment program to benefit persons with mental disabilities. Under an arrangement with the county social services department, she could hire Tyrone as a kitchen steward at the Hickory Bar \& Grill at one half the standard hourly rate. The county social services department would provide transportation to and from work and would supplement Tyrone's reduced income. It seemed to Leslie to be a promising start to introducing assisted programs to the Hightower, and she agreed to interview him.

After talking with Tyrone, Leslie determined that, although he would need some initial guidance and perhaps additional training, he was clearly capable of performing the duties of a steward in the kitchen. Likewise, Terry, the director of food and beverage for the Hickory, also felt Tyrone would work out and that he would be good for the department as well. They both were concerned, however, that although Tyrone appeared healthy and active, he was considerably overweight. At the time he was hired, he was 5'3" and weighed over 275 pounds.

In spite of his weight, the most striking quality about Tyrone was his contagiously positive attitude. Tyrone was bursting with enthusiasm, and his smile seemed to have an instant effect on everyone. As Leslie reflected on this period, she recalled how good she had felt as she welcomed Tyrone to the Hightower Hotel.

Questions:

(1) How much do you know about supported employment programs? 
(2) What is your opinion of this matching funds type of program for the employment of persons with mental disabilities?

(3) What other concerns would you have if you were in Leslie's position?

(4) Would you seek out a person with a mental disability as a potential employee on your property? What positions (other than steward) might such a person hold?

\section{The Training Period}

It became evident that Tyrone would indeed need additional training if he was to be successful at the Hightower. The director of the stewarding department, Pedro, realized there were certain assumptions made regarding employees that could not be made regarding Tyrone. The first set of obstacles was brought on by Tyrone's literacy difficulties. Tyrone was unable to find his own time card from among the collection of cards in the time clock area. In addition, he could not read neither his weekly schedule nor any of the information in the employee handbook or other employment documents. Although some of these problems could be addressed through creative problem-solving, others required substantial support mechanisms.

With regard to Tyrone's time card, the payroll department simply put a large red stripe on the top so that he could distinguish his card from others. Also, his weekly schedule was written in calendar form so he could better understand the times and dates.

Problems related to the employee handbook and other employment documents were not so different for Tyrone than they would be for any employee with English as a second language. A volunteer was found to read the handbook to Tyrone, after which he repeated key information and acknowledged that he understood the points. A little extra help was all it took for Tyrone to be successful in the stewarding department. He performed his job well and soon became a 
valuable member of the stewarding team. He had an excellent attendance record and was a very hard worker.

Small problems repeatedly arose, however, because of his limitations. For example, part of the responsibility of a steward was to sort silverware, china, and glassware. Tyrone had difficulty distinguishing the sizes and patterns of different plates, which lead to mistakes in stacking and storage of the various pieces. In response to this particular problem, Pedro put up life-size photographs of the plates, saucers, cups, and silverware. This enabled Tyrone to compare the dishes with the pictures and substantially reduced the number of errors and increased his efficiency.

Tyrone's willingness to learn and overcome obstacles, combined with his cheerful personality, led to his promotion from stewarding to supervisor of the employee cafeteria. His duties were to keep the food hot and fresh on the line, and to keep the cafeteria and serving area clean and well stocked.

\section{Questions:}

(1) Do you belive that the special accommodations made for Tyrone were reasonable and appropriate?

(2) Do you think that these accommodations would have been done for a nondisabled employee, if necessary?

(3) How do you think Tyrone's colleagues felt about the accommodations being made for him?

(4) Do you feel a promotion was in order? What are the possible negative consequences? 


\section{The Cafeteria}

Tyrone loved the interaction with other members of the hotel staff, and he was attentive and conscientious about the food preparation and cleanliness of the dining room. Tyrone flourished under these conditions. He would make sure every table was clean after each party left, and he would do extra things, such as pull out chairs for ladies and find extra chairs if people joined a group.

Tyrone's new visibility had another positive effect. He was doing so well that everyone noticed it, and soon he became quite popular throughout the hotel. This commaraderie lead to joking about his weight. This joking eventually became a competition with other employees to lose weight. Soon, everyone in the hotel was keeping track of how much weight Tyrone was losing; after six months, he had lost seventy pounds.

After slimming down, Tyrone also looked like a different person. His good looks were also a major topic of conversation among those who had supported him through his weight loss program. This attention lead to the development of some behaviors Tyrone had never experimented with before. For the first time he began to flirt with female employees eating in the cafeteria. At first it seemed innocent enough — in fact, the women were so delighted with Tyrone's improved appearance and so charmed by his vibrant personality that they returned his attention. Soon, however, his behavior became inappropriate. He began touching the women too often. He would stroke their hair, hold their hand, and even occasionally sneak a kiss from behind. Women employees began to feel uncomfortable and somewhat fearful. While some simply avoided the cafeteria, others complained.

Terry and Leslie talked with Tyrone several times about his behavior, and he was extremely apologetic. Unfortunately, after a few days the inappropriate behavior would resume. 
Tyrone did not seem to understand that his friendliness was offensive, even threatening, to some women.

He seemed unable to distinguish between an appropriate and an inappropriate manner of relating to women. During the next three months, Tyrone received all four of Hightower's progressive discipline actions. That morning, a committee of employee representatives had visited the human resources office with a petition and demanded that Leslie terminate Tyrone's employment. Unfortunately, Leslie knew that termination was the next step.

On the walk back to the hotel, Leslie reviewed her options. Tyrone could be transferred to a less public position, but there was no guarantee that that would solve the problem. Furthermore, it may not be equitable in terms of other employees she had terminated. It was not usual hotel policy to transfer a problem employee, and such a move may have a powerful negative effect on those who had been offended by Tyrone's behavior. Yet, Leslie was convinced that Tyrone did not understand that his behavior was inappropriate and simply did not have the social skills to make such a distinction. How could she turn him away after all they had been through together? What would happen to him if he were to be sent back to a sheltered workshop?

\section{Questions:}

(1) What options do you believe there are in resolving the Tale of Tyrone? What are the advantages and disadvantages of each to Tyrone, fellow employees, and others?

(2) What do you think Leslie should do about Tyrone?

(3) What might have prevented the problem from developing?

(4) Do you think this is a training problem? 
(5) What are some other examples of problems that might arise for the employee with a mental disability who may be helped to develop task-related skills but who will have much more difficulty developing the accompanying social skills?

(6) What issues of equity might arise when the disabled are introduced into the hospitality workplace? 